\title{
Nice guideline on thyroid disease: where does it take us with liothyronine?
}

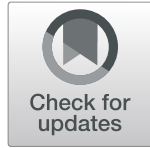

Graham P. Leese

\begin{abstract}
The new NICE guidelines on thyroid disease and its management do not recommend the routine use of liothyronine, but do not completely rule it out either. Guidelines from the British and European Thyroid Associations are open to a "trial of liothyronine" on an individual basis.

Some patients do not feel well on L-thyroxine despite a serum TSH in the reference range. Key issues to consider in such patients include establishing whether the patient had established hypothyroidism initially, and whether the Lthyroxine has been titrated carefully enough, possibly using small increments, to achieve a careful balance between symptoms and serum TSH concentrations. Patients should also be considered for other causes of the symptoms which may be wide-ranging.

Meta-analyses of several, but small, randomised control trials show no advantage, or disadvantage of liothyronine over L-thyroxine. However, detailed sub-analysis identifies some tantalising results eg on preferential weight loss, patient preference, and possibly genetic markers. Although linked with plausible theoretical explanations, these results may be over-interpreted. The key questions are whether a short-term trial treatment is worthwhile and safe, and whether in the future sub-groups of patients can be identified who may benefit from liothyronine. These questions remain divisive but require additional focussed research.

It could be argued that inflated costs of liothyronine in some countries have either distracted from or helped focus on the science. Costs need to be addressed. However better biomarkers of tissue level thyroid action, and a better understanding of the impact of genetic polymorphisms will help to make progress when choosing if there is a place for liothyronine in the future.

(words: 262)
\end{abstract}

Keywords: Liothyronine, L-thyroxine, Thyroid, Guidelines

\section{Background}

The debate on whether liothyronine has a role in managing hypothyroidism is akin to entering a cauldron where there is reasonably clear, but possibly weak, clinical evidence but with intriguing and tantalising questions in the detail, alongside a strong patient lobby, Pharmaceutical financial opportunism and Politicians who are conflicted between a popularist approach and a need for fiscal responsibility in health-care.

Correspondence: grahamleese@nhs.net

Ward 5 Ninewells Hospital, Dundee DD1 9SY, UK

\section{Sorting L-thyroxine prescribing first of all}

Titrating the correct dose of L-thyroxine for patients with primary hypothyroidism is usually straight-forward but can be challenging in some patients, as around 5$10 \%$ of patients on L-thyroxine have persistent symptoms after starting treatment [1, 2]. The goal is to achieve a balance between symptomatic improvement and maintaining a serum thyroid-stimulating hormone (TSH) concentration in the reference range so as to avoid adverse events [3]. Several patients do seem to prefer a dose of L-thyroxine that results in a serum TSH in the lower part of the reference range, and some even

(c) The Author(s). 2020 Open Access This article is licensed under a Creative Commons Attribution 4.0 International License, which permits use, sharing, adaptation, distribution and reproduction in any medium or format, as long as you give appropriate credit to the original author(s) and the source, provide a link to the Creative Commons licence, and indicate if changes were made. The images or other third party material in this article are included in the article's Creative Commons licence, unless indicated otherwise in a credit line to the material. If material is not included in the article's Creative Commons licence and your intended use is not permitted by statutory regulation or exceeds the permitted use, you will need to obtain permission directly from the copyright holder. To view a copy of this licence, visit http://creativecommons.org/licenses/by/4.0/ The Creative Commons Public Domain Dedication waiver (http://creativecommons.org/publicdomain/zero/1.0/) applies to the data made available in this article, unless otherwise stated in a credit line to the data. 
with a serum TSH below the reference range. The availability of 12.5 microgram dose strengths of L-thyroxine makes this titration easier. However, patients are increasingly being started on L-thyroxine at more marginal baseline serum TSH concentrations [4] often with transient or marginally abnormal serum TSH where hypothyroidism is unlikely to be the cause of their symptoms. We now realise that the reference range should probably be expanding, especially in older patients [5]. Some patients do not gain persistent benefit with increasing doses of L-thyroxine despite achieving a low or even suppressed TSH. Thus careful consideration of many other potential causes of their symptoms should be considered, including important conditions such as hypoadrenalism and anaemia. However, co-prescribed drugs, sleep apnoea, chronic fatigue, stressful lifestyles are all more common causes of symptoms that may be mistaken for non-specific hypothyroid symptoms.

The new National Institute for Clinical Excellence (NICE) guidelines [6] recommend using L-thyroxine, with no routine use of liothyronine (section 1.3.4). For healthy people under the age of 65 a dose of 1.6microgram $/ \mathrm{kg}$ body weight/day is advised from the start, whilst those over 65 years or with a history of cardiovascular disease should be started on 25 or 50 microgram of L-thyroxine. The dose should be adjusted to achieve a serum TSH within the reference range, acknowledging that the serum TSH can take some time to change. Most clinicians will adjust the dose of thyroxine being guided by both symptom control and serum TSH. This acknowledges that a number of different L-thyroxine doses may be compatible with a serum TSH in the reference range.

\section{Main text}

\section{Is there a role for Liothyronine?}

The NICE guidelines [6] do comment that some patients who do not feel well on L-thyroxine alone "are sometimes offered liothyronine". The guideline does not give a clear recommendation to use Liothyronine but imply that there may be a role for liothyronine for patients with adverse symptoms despite seemingly adequate Lthyroxine replacement, and that more research is required. The British Thyroid Association [7] and European Thyroid Association [8] provide clearer guidance. For patients not achieving adequate symptom control on L-thyroxine where other potential causes of the symptoms have been excluded, they suggest that Liothyronine in combination with L-thyroxine may be considered by a specialist Endocrinologist on a trial basis whilst maintaining the serum TSH in the reference range. The trial of liothyronine should be stopped after $3-4$ months if there is no patient benefit. However, across the UK the approach to liothyronine prescribing has been very variable. In some areas it has proved virtually impossible to access it, in others there is a fairly restricted approach, whilst in a decreasing number of areas it has been more freely available.

\section{Is Liothyronine beneficial or harmful compared to L- thyroxine?}

Meta-analyses have compared liothyronine use (alone or in combination with L-thyroxine) against L-thyroxine alone, but demonstrated no consistent benefit for liothyronine use over L-thyroxine alone $[6,9,10]$. Unfortunately, only three of the original studies included more than 100 patients, and many are under powered. It has been concluded that liothyronine demonstrates no overall benefit and in addition there may be risks. Current forms of oral liothyronine cause transient nonphysiological elevated serum tri-iodothyronine concentrations post-dosing [11], which are not thought to result in low serum TSH concentrations but may still be harmful. More flexible dosing regimes of liothyronine aided by the introduction of 5 microgram tablets, could make liothyronine dosing easier and potentially safer if they reduced the risk of raised serum tri-iodothyronine, although they are unlikely to eliminate this risk. Other options would include the use of a slow-release preparation of liothyronine which is being explored.

These same meta-analyses $[6,9,10]$ could be interpreted that liothyronine is not inferior to L-thyroxine, and the lack of difference in adverse events [9] as reassuring. A 17 year population-based observational follow up study with 400 people on liothyronine also showed no increase risk of fractures, atrial fibrillation or cardiovascular disease [12] with patients achieving a mean serum TSH of $1.1 \mathrm{mU} / \mathrm{L}$ during follow up, although there was an increased risk of prescription for incident psychotropic medication. Intriguingly some studies showed marginally enhanced weight loss $(\sim 1.5$ $\mathrm{kg}$ ) on a liothyronine/L-thyroxine combination compared to L-thyroxine alone, whilst patients were maintaining a serum TSH in the reference range [13, 14]. Also in five cross-over studies more patients preferred combination therapy rather than L-thyroxine alone ( $48 \%$ vs $27 \%$ - [8]). It is thus possible that there is a subset of patients who may benefit from liothyronine. Is there a potential rationale for this or are these findings due to random chance?

L-thyroxine replacement results in higher serum free thyroxine (T4) concentrations which suppresses deiodinase activity and lowers serum T3 concentrations. Rat studies required a combination of thyroxine and liothyronine replacement to achieve physiological tissue serum concentrations [15]. However, similar studies in humans did not seem to result in improved patient reported outcomes $[8,16]$ and in another study serum $\mathrm{T} 4$ and serum 
triodothyronine (T3) concentrations were no different between self-reported "responders" and non-responders" to liothyronine therapy [17]. This may be because intracellular concentrations of T3 are dependent on a huge number of factors, including membrane transport proteins, de-iodination, nuclear protein binding e.g. with retinoid X receptor (RXR) and thyroid hormone receptors, which are all downstream from serum concentrations of thyroid hormones. Hence measuring serum free thyroxine and liothyronine may not be the way to understand this enigma and we may need novel biomarkers . Intriguingly other biomarkers have been used in some studies, and despite similar serum TSH concentrations, use of liothyronine resulted in lower serum cholesterol, higher sex hormone binding globulin (SHBG) and increased markers of bone turnover [18-20]. We cannot however ignore serum TSH, which we do know is a useful marker of long-term patient safety of fractures and cardiovascular disease [3]. It may be a blunt marker however with risks increasing significantly only when the serum $\mathrm{TSH}$ was below $0.1 \mathrm{mU} / \mathrm{l}$, despite the lower limit of the reference range being $0.4 \mathrm{mU} / \mathrm{L}$.

The main enzyme converting $\mathrm{T} 4$ to $\mathrm{T} 3$ in tissues is deiodinase 2 (DIO2). Thus the initial studies showing that a polymorphism on the DIO2 gene was associated with a better response to liothyronine than the wild type [2] was intuitive and exciting. However further studies have not corroborated this finding in follow up [21]. Other polymorphisms on the monocarboxylate transporter 10 (MCT10) thyroid transporter protein, especially in combination with DIO2 polymorphisms have also been potentially implicated [22]. Genetic epidemiology is however fraught with false dawns, especially when studying candidate genes and much larger study cohorts with replication studies, and GWAS studies are required in this area before any conclusions can be drawn.

\section{Costs of Liothyronine}

The astronomical increase in costs of liothyronine over the last 10 years in the UK has resulted in a focus on the benefits and risks of liothyronine that probably would otherwise have received less attention given the age of the drug liothyronine. With the price of liothyronine 20 microgram peaking at around $£ 250$ per month in the UK, and following parliamentary activity from the House of Lords, the number of suppliers has increased from one to three and the price is starting to fall, currently being available at $£ 174$ per month (at the time of writing). However this compares with a cost of around $£ 4$ ten years ago, a cost of about $£ 6$ per month in Germany and an equivalent dose cost of around $£ 1$ per month for Lthyroxine. This has also resulted in post-code prescribing, with patients in the most deprived parts of England being half as likely to receive a prescription for liothyronine as people in the most affluent areas [23].

\section{Pragmatic approach for now}

Thus in summary there is no robust data that liothyronine is of benefit in patients requiring thyroid replacement, which is why guidelines recommend that the vast majority of patients should be treated with L-thyroxine. However there are patient reports of benefit and some intriguing data which may support this. There appears to be no apparent major risks of using liothyronine as long as the serum TSH is maintained within the reference range. Thus careful judicious use of liothyronine use may be warranted in a few patients who continue to report adverse symptoms that cannot be attributed to another cause $[7,8]$. Using a combination of L-thyroxine and liothyronine avoids the need for high doses of liothyronine, and may thus avoid the concerns of hyperthyroxinaemia, although it seems this cannot be eliminated with current formulations [11]. Most studies use a ratio of $1: 5$ or 1:4 for Liothyronine to L-thyroxine, but some have used a 1:3 or a 1:10 ratio. There is no clear consensus about equivalent doses of L-thyroxine and Liothyronine but most clinicians reduce the former by 50microgram and introduce 10-20 microgram of liothyronine [16]. A long acting preparation of liothyronine is also being explored with the consideration of it being safer.

\section{What do we need to improve the situation for patients?}

Firstly we need to address inappropriate initiation, or continuation of L-thyroxine. When patients are started on L-thyroxine inappropriately it is not surprising that they may not feel better on treatment. There is a great desire to address a patient's feelings of lack of well being, and coupled with the often non-specific symptoms that can be associated with hypothyroidism and in the presence of a borderline serum TSH result it is understandable to consider treating with L-thyroxine. Thus, for individuals in such circumstances it may reasonable to start a "trial" of L-thyroxine for around three months. Sometimes there can be an immediate benefit but if the clinical benefit is not maintained then treatment should not be continued in patients with a baseline borderline serum TSH, as otherwise it raises unrealistic expectations about the role of L-thyroxine for them in the longterm.

Secondly we need better biomarkers to measure the impact of thyroid replacement therapy. Serum TSH is probably the best one we have currently, but serum free$\mathrm{T} 4$ and serum free-T3 concentrations in general do not reflect the complex intracellular homeostasis of thyroid physiology. 
Most of the randomised controlled clinical trials of liothyronine are too small to address some of the clinical endpoints that are being measured. Some trials may include patients where the initial diagnosis of hypothyroidism was questionable but have been established on L-thyroxine as explained above. Future trials of liothyronine should only include patients where the diagnosis of hypothyroidism is robust, such as having a TSH of greater than $10 \mathrm{mU} / \mathrm{L}$ or a serum free T4 below the reference range prior to diagnosis. However, the current trials identify some intriguing results on the use of liothyronine e.g. weight changes and genetic studies, which suggest that some subgroups may benefit more than others, but the trials are too small to draw useful conclusions. Also it may be best to focus research on patients who feel unwell on L-thyroxine rather than including all patients with hypothyroidism [6]. In addition as there is a suggestion of variable tissue level effects eg brain versus liver, further exploration of the differential impact of liothyronine on symptoms eg brain fog versus fatigue, may be warranted.

Fourthly, the issue of pricing for liothyronine in the UK needs to be addressed. Why has the price been allowed to increase so much in the last 10 years? Why is the price so much more than other European countries e.g. more than 30 -fold greater? Why has it not decreased more since the introduction of multiple suppliers and the breaking of the previous monopoly? There is a need for procurement teams to negotiate better deals.

\section{Conclusion}

There is a sense that the issues surrounding the use of liothyronine are like a storm in a teacup whipped up by the winds of pricing. However there are real issues about benefit and risk which remain scientifically unresolved unfortunately. A pragmatic approach has been outlined, but in the future we need to move towards identifying if there are any subgroups of hypothyroid patients who may benefit from using liothyronine in addition to Lthyroxine, probably by identifying novel biomarkers or genetic polymorphisms.

\section{Acknowledgements}

None.

\section{Author's contributions \\ Graham Leese was sole author and contributed ideas and writing. The author read and approved the final manuscript.}

\section{Funding}

there was no funding for this work.

\section{Availability of data and materials}

There is no original data and no materials available.

Ethics approval and consent to participate

As this is a commentary no ethics or consent was sought.
Consent for publication

No consent for publication was sought.

\section{Competing interests}

There are no competing interests.

Received: 19 March 2020 Accepted: 12 May 2020

Published online: 23 May 2020

\section{References}

1. Wekking EM, Appelhof BC, Fliers E, Schene AH, Huyser J, Tijssen JGP, Wiersinga WM. Cogntive functioning and well-being in euthyroid patients on thyroxine replacement for primary hypothyroidism. Eur J Endo. 2005;155: 747-53.

2. Panicker V, Saravanan P, Vaidya B, Evans J, Hattersley AT, Frayling TM, et al. Common variation in the $\mathrm{DIO} 2$ gene predicts baseline psychological wellbeing and response to combination thyroxine plus triiodothyronine therapy in hypothyroid patients. J Clin Endocrinol Metab. 2009;94:1623-9.

3. Flynn RV, Bonellie SR, Jung RT, MacDonald TM, Morris AD, Leese GP. Serum thyroid stimulating hormone concentration and morbidity from cardiovascular disease and fractures in patients on long-term Thyroxine therapy. J Clin Endo and Met. 2010;95:186-93.

4. Taylor PN, lqbal A, Minassian C, Sayers A, Draman MS, Greenwood R, Hamilton W, Okosieme O, Panicker V, Thomas SL, Dayan C. Falling threshold for treatment of borderline elevated thyrotropin levels-balancing benefits and risks: evidence from a large community-based study. JAMA Intern Med. 2014;174:32-9.

5. Vadiveloo T, Donnan PT, Murphy MJ, Leese GP. Age- and gender-specific TSH reference intervals in people with no obvious thyroid disease in Tayside, Scotland: the thyroid epidemiology, audit and research study (TEARS) J Clin Endo Metab 2013; 98: 1147-53.

6. NICE guideline (NG 145). Thyroid disease: assessment and management https://www.nice.org.uk/guidance/ng145/evidence/e-management-ofhypothyroidism-pdf-6967421681 (last accessed 20/01/2020).

7. Okosieme O, Gilbert J, Abraham P, Boelaert K, Dayan C, Gurnell M, Leese G, McCabe C, Perros P, Smith V, Williams G, Vanderpump M. Management of primary hypothyroidism: statement by the British thyroid association executive committee. Clin Endo. 2016;84:799-808.

8. Wiersinga WM, Duntas L, Fadeyev V, Nygaard B, Vanderpump MP. 2012 ETA guidelines: the use of $\mathrm{L}-\mathrm{T} 4+\mathrm{L}-\mathrm{T} 3$ in the treatment of hypothyroidism. European Thyroid Journal. 2012;1:55-71.

9. Grozinsky-Glasberg S, Fraser A, Nahshoni E, Weizman A, Leibovici L. Thyroxinetriiodothyronine combination therapy versus thyroxine monotherapy for clinicalhypothyroidism: meta-analysis of randomized controlled trials. J Clin Endocrinol Metab. 2006;91:2592-9.

10. Ma C, Xie J, Huang X, Wang G, Wang Y, Wang X, et al. Thyroxine alone or thyroxine plus triiodothyronine replacement therapy for hypothyroidism. Nucl Med Commun. 2009:30:586-93.

11. Jonklass J, Burmam KD. Daily administration of short acting liothyronine is associated with significant serum triiodothyronine excursions and fails to alter thyroid responsive parameters. Thyroid 2016; 26: 770-778.

12. Leese GP, Soto-Pedre E, Donnelly L. Liothyronine use in a 17 year observational population-based study- the TEARS study. Clin Endo. 2016;85: 918-25.

13. Appelhof BC, Fliers $E$, Wekking EM, Schene AH, Huyser J, Tijssen JG, et al Combined therapy with levothyroxine and liothyronine in two ratios, compared with levothyroxine monotherapy in primary hypothyroidism: a double-blind, randomized, controlled clinical trial. J Clin Endocrinol Metab. 2005:90:2666-7.

14. Nygaard B, Jensen EW, Kvetny J, Jarlov A, Faber J. Effect of combination therapy with thyroxine (T4) and 3,5,3'-triiodothyronine versus T4 monotherapy in patients with hypothyroidism, a double-blind, randomised cross-over study. Eur J Endocrinol. 2009;161:895-902.

15. Escobar-Morreale HF, Escobar del Rey F, Obergon MJ, Morreale de Escobar G. Only combined treatment with thyroxne and tri-iodothyronine ensures euthyroidism in all tissues of the thyroidectomised rat. Endoc. 1996;137: 2490-502.

16. Wiersinga WM. Therapy of endocrine disease: $\mathrm{T} 4+\mathrm{T} 33$ combination therapy: is there a true effect? Eur J Endocrinol. 2017;177:R287-96.

17. Medicii M, Chaker L, Peeters RP. A step forward in understanding the relevance of genetic variation in type-2 deiodinase. JCEM. 2017;102:1775-8. 
18. Fadeyev W, Morgunova TB, Melnichenko GA, Dedov II. Combined therapy with $\mathrm{Lthyroxine}$ and $\mathrm{L}$-triiodothyronine compared to $\mathrm{L}$-thyroxine alone in the treatment of primary hypothyroidism. Hormones. 2010;9:245-52.

19. Schmidt U, Nygaard B, Jensen EW, Kvetny J, Jarlov A, Faber J. Peripheral markers of thyroid function: the effect of T4 monotherapy vs T4/T3 combination therapy in hypothyroid subjects in a randomized crossover study. Endocrine Connections. 2013; 2:55-60 49. Shatynska-Mytsyk I,

20. Celi FS, Zemskova M, Linderman JD, Babar NI, Skarulis MC, Csako G, Wesley $R$, Costello R, Penzak SR, Pucino F. The pharmacodynamics equivalence of levothyroxine and liothyronine: a randomised double-blind cross-over trial of liothyronine versus levothyroxine. JCEM. 2011;96:3466-74.

21. Wouters HJCM, van Loon HCM, van der Klauw MM, Elderson MF, Slagter SN, Muller Kobold A, Kema IP, Links TP, van-Vilet-Ostaptchouck JV, Wolffenbuttel BHR. No effect of the Thr92Ala polymorphism of deiodinase-2 on thyroid hormone parametes, health related quality of life and cognitive functioning in a large population-based cohort study. Thyroid 2017; 27: 147-155.

22. Carle A, Faber J, Steffensen R, Laurberg P, Nygaard B. Hypothyroid patients encoding combined MCT10 and DIO2 gene polymorphisms may prefer LT3 + L-T4 combination treatment - data using a blind, randomized. Clinical Study European Thyroid Journal. 2017;6:143-51.

23. Taylor PN, Razvi S, Muller I, Wass J, Dayan CM, Chaterjee K, Boelaert K. Liothyronine costs and prescriptions in England. Lancet Diabetes and Endocrinology. 2019;7:11-2.

\section{Publisher's Note}

Springer Nature remains neutral with regard to jurisdictional claims in published maps and institutional affiliations.

Ready to submit your research? Choose BMC and benefit from:

- fast, convenient online submission

- thorough peer review by experienced researchers in your field

- rapid publication on acceptance

- support for research data, including large and complex data types

- gold Open Access which fosters wider collaboration and increased citations

- maximum visibility for your research: over $100 \mathrm{M}$ website views per year

At $\mathrm{BMC}$, research is always in progress.

Learn more biomedcentral.com/submissions 